\title{
ANALISIS MINAT DAN MOTIVASI DALAM PENULISAN KARYA ILMIAH PADA MAHASISWA PROGRAM STUDI PENDIDIKAN MATEMATIKA UNIVERSITAS FLORES
}

\author{
Maria Waldetrudis Lidi, Ningsih \\ Program Studi Pendidikan Matematika, FKIP, Universitas Flores \\ e-mail: waldertrudismaria1024@gmail.com
}

\begin{abstract}
One effort to improve the education is by doing research because it can improve someone competence which is found by the motivation and needs in developing a scientific writing. This research is a descriptive qualitative. Subject of this research is analyzing the students' needs and motivation in mathematics study program toward ability to write a scientific writing for academic years 2015/2016 with involved 109 students in semester II to semester VI randomly. This research was conducted at Mei-June 2016. Data collection was taken by giving the questionaire. Due to the result of the analysis, and discussion so that it can conclude that students' need to write the scientic writing $70 \%$ is categorized strong, meanwhile intrinsinc motivation is strongest than extrinsic motivation. It can show by the data of students' extrinsinc motivation is 55\%, meanwhile intrinsic motivation is strongest is about $92 \%$.
\end{abstract}

Keywords: Needs, Motivation, Scientific writing

\begin{abstract}
ABSTRAK: Salah satu upaya untuk meningkatkan pendidikan yakni dengan melakukan penelitian agar dapat meningkatkan kompetensi seseorang, yang salah satunya dapat dibuktikan melalui suatu karya tulis ilmiah. Penelitian ini merupakan jenis penelitian kualitatif deskriptif. Subjek dalam penelitian ini adalah minat dan motivasi mahasiswa Program Studi Pendidikan Matematika terhadap penulisan karya ilmiah. Penelitian ini melibatkan 109 mahasiswa pada semester II sampai semester VI diambil secara acak. Waktu Penelitian dilaksanakan pada bulan Mei-Juni 2016. Teknik pengambilan data dilakukan dengan penyebaran angket. Berdasarkan hasil analisis dan pembahasan, maka dapat dibuat simpulan bahwa minat mahasiswa pendidikan matematika dalam menulis karya ilmiah masuk kategori kuat karena berada pada kisaran di atas 70\%. Motivasi intrinsik mahasiswa dalam menulis karya ilmiah lebih kuat daripada motivasi ekstrinsik. Hal ini ditunjukkan dengan data motivasi ekstrinsik mahasiswa sebesar 55\% sedangkan nilai motivasi instrinsik yang jauh lebih kuat yaitu sebesar $92 \%$.
\end{abstract}

Kata kunci: Minat, Motivasi, Karya Ilmiah 


\section{PENDAHULUAN}

Pendidikan menjadi satu titik tolak pengembangan sumber daya manusia yang berkualitas. Oleh karena itu pendidikan harus dimulai dari lingkup yang paling kecil yaitu keluarga, sekolah dan masyarakat dimana kita tinggal. Lingkup-lingkup tersebut akan membentuk sikap, tindakan serta intelektual kita agar sesuai dengan norma dan aturan yang berlaku dalam masyarakat. Senada dengan tujuan pendidikan tersebut, pemerintah menetapkan UU No. 20 Tahun 2003 tentang Sistem Pendidikan Nasional yang menyatakan bahwa "Pendidikan adalah usaha sadar terencana untuk mewujudkan suasana belajar dan proses pembelajaran agar peserta didik secara aktif mengembangkan potensi dirinya untuk memiliki kekuatan spiritual keagamaan, pengendalian diri, kepribadian, kecerdasan, akhlak mulia, serta keterampilan yang diperlukan darinya, masyarakat, bangsa, dan negara".

Pelaksanaan pendidikan di sekolah adalah suatu proses pembelajaran yang paling penting dimana keberhasilan pencapaian tujuan pendidikan akan dicapai melalui proses pembelajaran yang efektif. Seorang guru harus dituntut agar mampu memahami bagaimana pembelajaran yang dapat mempengaruhi siswa agar dapat berperan aktif dalam proses pembelajaran tersebut. Hal ini pun ditekankan oleh UNESCO bahwa institusi pendidikan harus dapat menyelenggarakan proses pembelajaran yang bertumpu pada empat pilar pendidikan yaitu; 1). Pilar learn to know bermakna bahwa pembelajaran merupakan proses "menjadi tahu" dari sebelumnya yang 'tidak mengetahui" sesuatu. Peserta didik dibekali dengan pengetahuan yang dibutuhkan untuk mengembangkan intelektualitasnya; 2) Pilar learn to do mempunyai makna bahwa setelah atau bersamaan dengan peserta didik mendapat pembekalan pengetahuan, ia harus menerima pula bekal berikutnya yaitu kemampuan yang bersifat keterampilan dalam mengerjakan sesuatu, yang tercakup dalam ranah psikomotor; 3 ). Pilar learn to be merupakan pembekalan untuk menyempurnakan dua pilar sebelumnya, yaitu bahwa setelah peserta didik memiliki pengetahuan dan keterampilan, langkah selanjutnya tentunya dengan berbekal ilmu penegtahuan dan teknologi, maka si pemilik ilmu pengetahuan dan teknologi itu harus dapat mendayagunakannya untuk tercapainya kemanfaatan; 4). Pilar learn to live together merupakan upaya memadukan ketiga pilar yang terdahulu dan terimplementasikan dalam kehidupan nyata di masyarakat (Kristiawan, 2015).

Berkaitan dengan keempat pilar tersebut, program studi pendidikan Matematika Universitas Flores turut serta mengambil bagian dalam menjalankan proses perkuliahan guna menciptakan output yang berkualitas dan mampu berdaya saing dalam perkembangan 
globalisasi. Namun tidak dipungkiri bahwa mahasiswa program studi pendidikan Matematika masih perlu dibekali dengan pengetahuan dan keterampilan yang lebih baik sehingga mereka mampu melihat realita dan permasalahan yang terjadi dalam lingkungan sekitarnya.

Dalam upaya penyelesaian permasalahan yang terjadi di dalam masyarakat tersebut, mahasiswa perlu menyelesaikannya melalui suatu proses penelitian ilmiah. Penelitian ilmiah merupakan suatu karya ilmiah yang dilakukan oleh seorang peneliti agar memperoleh hasil yang lebih terpercaya. Seperti yang dikatakan oleh Sudirman (2012), karya ilmiah adalah suatu karangan atau tulisan yang diperoleh sesuai dengan sifat keilmuannya dan didasari oleh hasil pengamatan, peninjauan, penelitian dalam bidang tertentu, disusun menurut metode tertentu dengan sistematika penulisan yang bersantun bahasa dan isinya dapat dipertanggungjawabkan kebenarannya/keilmiahannya. Karya ilmiah memiliki bentuk yang berbeda sesuai dengan fungsinya, seperti makalah, jurnal, skripsi, tesis dan disertasi. Menurut Dirjen Pendidikan Tinggi Tahun 2014 mendefenisikan karya ilmiah sebagai suatu hasil penelitian atau pemikiran yang dipublikasikan dan ditulis dengan memenuhi kaidah ilmiah dan etika keilmuan (Widyahening, 2015).

Karya tulis ilmiah dapat dihasilkan bergantung pada minat dan motivasi individu karena minat dan motivasi dari seseorang tentu akan berdampak pada produk ilmiah yang dihasilkan.

Minat (interest) adalah suatu bentuk motivasi intrinsik. Siswa yang mengejar suatu tugas yang menarik minatnya mengalami efek positif yang signifikan seperti kesenangan, kegembiraan, dan kesukaan (Hidi, Renninger, Krapp, 2004; Schiefele, 1998 dalam Ormrod, 2008) sedangkan motivasi adalah apa yang membuat anda berbuat, membuat anda tetap berbuat, dan menentukan ke arah mana yang hendak anda berbuat Slavin (2011).

Berdasarkan uraian tentang tujuan penulisan karya ilmiah di atas, maka dalam penelitian ini perlu menganalisis seberapa jauh minat dan motivasi mahasiswa program studi pendidikan Matematika dalam menulis karya ilmiah. Adapun rumusan masalah dirumuskan sebagai berikut, Bagaimanakah minat dan motivasi mahasiswa program studi pendidikan Matematika dalam menyusun karya ilmiah?

\section{LANDASAN TEORI}

Dalam proses penulisan memerlukan bahan berupa ide, pemikiran, pengalaman, penemuan, teori, dan hasil penelitian yang diperoleh melalui membaca begitu pun sebaliknya. Teori, ide, pemikiran, pengalaman dan wawasan yang dimiliki itu tak ada artinya apabila 
tidak disampaikan dan tidak dikembangkan lebih lanjut. Menulis merupakan proses penuangan gagasan dan pemikiran dengan sistem tertentu dalam bentuk tulisan. Gagasan yang tidak ditulis atau tidak didokumentasikan akan hilang begitu saja (Lasa, 2009).

Menurut Kamus besar bahasa indonesia, karya berarti pekerjaan, hasil perbuatan, buatan, ciptaan atau hasil ciptaan yang bukan salinan atau terjemahan atau bukan tiruan sedangkan ilmiah adalah bersifat ilmu dan secara ilmu pengetahuan, memenuhi syarat (kaidah) ilmu pengetahuan atau hal yang berlandaskan kepada ilmu pengetahuan. Jadi disimpulkan bahwa karya ilmiah atau adalah karya tulis hasil ciptaan yang bukan salinan atau terjemahan atau bukan tiruan yang dibuat dengan prinsip-prinsip ilmiah, berdasarkan data dan fakta.

Motivasi adalah proses internal yang mengaktifkan, menuntun dan mempertahankan perilaku dari waktu ke waktu. Ada banyak jenis, intensitas, tujuan, dan arah motivasi yang berbeda-beda (Slavin, 2011). Pengertian motivasi disederhanakan oleh Nur (2008), motivasi adalah apa yang membuat anda berbuat, membuat anda tetap berbuat, dan menentukan ke arah mana yang hendak anda berbuat. Motivasi untuk melakukan sesuatu dapat muncul dalam berbagai bentuk. Lebih lanjut dijelaskan oleh Nur, motivasi dapat merupakan suatu sifat pribadi atau kepribadian seseorang; individu tertentu dapat memiliki minat yang stabil dan tahan lama dalam berperan serta pada berbagai kategori kegiatan yang begitu luas seperti akademik, olahraga, atau kegiatan sosial.

Menurut Sanjaya (2011), motivasi adalah dorongan yang timbul dalam diri seseorang untuk melakukan berbagai usaha dan aktivitas dalam rangka memenuhi kebutuhan untuk mencapai tujuan tertentu. Tinggi rendahnya motivasi dapat menentukan tinggi rendahnya usaha atau semangat seseorang untuk beraktivitas, dan tinggi rendahnya semangat akan menentukan hasil yang diperoleh. Hal ini didukung oleh Sumiati dan Asra (2007), yang menyatakan bahwa motivasi pada dasarnya merupakan keinginan (wants) yang ingin dipenuhi (dipuaskan), motivasi timbul bila ada rangsangan, baik karena adanya kebutuhan (needs) maupun minat (interest) terhadap sesuatu.

Menurut Makmun (2012), meskipun motivasi itu merupakan suatu kekuatan, namun tidaklah merupakan suatu substansi yang dapat kita amati. Yang dapat kita lakukan adalah mengidentifikasi beberapa indikatornya dalam term-term tertentu, antara lain:

1. Durasinya kegiatan (berapa lama kemampuan penggunaan waktunya untuk melakukan kegiatan);

2. Frekuensinya kegiatan (berapa sering kegiatan dilakukan dalam periode waktu tertentu); 
3. Persistensinya (ketetapan dan kelekatannya) pada tujuan kegiatan;

4. Ketabahan, keuletan, dan kemampuannya dalam menghadapi rintangan dan kesulitan untuk mencapai tujuan;

5. Devosi (pengabdian) dan pengorbanan (uang, tenaga, pikiran, bahkan jiwanya atau nyawanya) untuk mencapai tujuan;

6. Tingkatan aspirasinya (maksud, rencana, cita-cita, sasaran, atau target, dan idolanya) yang hendak dicapai dengan kegiatan yang dilakukan;

7. Tingkatan kualifikasi prestasi atau produk atau output yang dicapai dari kegiatannya (berapa banyak, memadai atau tidak, memuaskan atau tidak);

8. Arah sikapnya terhadap sasaran kegiatan (suka atau tidak suka; positif atau negatif).

Motivasi dibagi dalam dua jenis yaitu motivasi intrinsik dan motivasi ekstrinsik. Menurut Sardiman (2011), motivasi intrinsik adalah motif-motif yang menjadi aktif atau berfungsinya tidak perlu dirangsang dari luar, karena dalam diri setiap individu sudah ada dorongan untuk melakukan sesuatu sedangkan motivasi ekstrinsik adalah motif-motif yang aktif dan berfungsinya karena adanya perangsang dari luar. Pernyataan ini didukung oleh Ormrod (2008), motivasi ekstrinsik adalah motivasi yang disebabkan oleh faktor-faktor eksternal individu dan tidak berkaitan dengan tugas yang sedang dilakukan sedangkan motivasi intrinsik adalah motivasi yang disebabkan oleh faktor-faktor di dalam diri atau melekat dalam tugas yang sedang dilakukan. Motivasi intrinsik akan bertahan dalam diri siswa dalam jangka waktu jangka panjang. Motivasi intrinsik mendorong mereka memahami dan menerapkan apa yang telah mereka pelajari, serta akan meningkatkan keingintahuan mereka untuk terus membaca dan belajar tentang menulis, sains, sejarah dan mata pelajaran lainnya setelah mereka lulus.

Minat (interest) adalah suatu bentuk motivasi intrinsik. Siswa yang mengejar suatu tugas yang menarik minatnya mengalami efek positif yang signifikan seperti kesenangan, kegembiraan, dan kesukaan (Hidi, Renninger, Krapp, 2004; Schiefele, 1998 dalam Ormrod, 2008). Minat persepsi bahwa suatu aktivitas menimbulkan rasa ingin tahu dan menarik; biasanya disertai oleh keterlibatan kognitif dan afek yang positif (Ormrod, 2008). Menurut Sardiman (2011), minat diartikan sebagai suatu kondisi yang terjadi apabila seseorang melihat ciri-ciri atau arti sementara situasi yang dihubungkan dengan keinginan-keinginan atau kebutuhan-kebutuhannya sendiri. Minat tidak timbul secara tiba-tiba melainkan timbul akibat dari partisipasi, pengalaman, kebiasaan pada waktu belajar atau bekerja. 
Minat dibagi atas dua jenis yaitu minat situasional dan minat pribadi. Minat situasional dipicu oleh sesuatu di lingkungan sekitar. Hal-hal baru, berbeda, tak terduga, atau secara khusus hidup sering menghasilkan minat situasional, demikian pula hal-hal yang melibatkan tingkat aktivitas yang tinggi atau emosi yang kuat sedangkan minat pribadi adalah minat yang berasal dari dalam pribadi yang bersifat jangka panjang dan relatif stabil pada suatu topik atau aktivitas.

Guru sebagai komponen penting yang mempengaruhi keberhasilan suatu proses pembelajaran perlu terus meningkatkan kompetensi diri yakni meningkatkan profesionalitas guru. Salah satu kompetensi guru yang perlu ditingkatkan adalah kompetensi profesional. Kompetensi profesional adalah kompetensi yang berhubungan dengan tugas seorang guru. Salah satu kemampuan yang berkaitan dengan kompetensi profesional adalah kemampuan dalam melaksanakan penelitian dan berpikir ilmiah untuk meningkatkan kinerja. Kemampuan ini kini diwajibkan oleh pemerintah untuk dimiliki oleh semua guru. Penelitian membantu guru untuk mengembangkan ide, gagasan, atau pengalaman yang dimilikinya untuk dituangkan dalam bentuk tulisan. Melalui hasil penelitian yang dituangkan dalam bentuk tulisan, pembaca khususnya rekan sesama guru dapat memperoleh informasi dan menambah wawasan khususnya yang berkaitan dengan pendidikan. Guru-guru pada akhirnya dapat berbagi pengalaman khususnya dalam memecahkan masalah yang dihadapi dalam pembelajaran demi peningkatan hasil belajar siswa.

\section{METODE PENELITIAN DAN ANALISIS}

Penelitian ini merupakan jenis penelitian kualitatif deskriptif. Subjek dalam penelitian ini adalah analisis minat dan motivasi mahasiswa program studi pendidikan matematika terhadap penulisan karya ilmiah tahun ajaran 2015/2016. Penelitian ini melibatkan 109 mahasiswa pada semester II sampai semester VI diambil secara acak. Waktu Penelitian dilaksanakan pada bulan Mei-Juni 2016 . Tempat Penelitian Program Studi Pendidikan Matematika di Univeristas Flores pada semester genap 2015/2016.

Teknik pengambilan data dilakukan dengan penyebaran angket untuk mengetahui berapa besar motivasi mahasiswa program studi pendidikan matematika terhadap penulisan karya ilmiah Penelitian ini dilakukan dalam dua tahap yaitu tahap pertama adalah tahap penyebaran angket tentang minat dan motivasi mahasiswa dan tahap kedua adalah analisis minat dan motivasi mahasiswa dalam penulisan karya ilmiah. Angket yang disebarkan adalah 
angket tertutup yang terdiri dari 20 pertanyaan dengan jumlah responden sebanyak 109 orang.

Analisis hasil minat dan motivasi mahasiswa dalam penulisan karya ilmiah dalam penelitian ini adalah menggunakan deskriptif kuantitatif dan kualitatif untuk memberikan deskripsi minat dan motivasi mahasiswa dalam menulis karya ilmiah. Data hasil penyebaran angket minat dan motivasi mahasiswa dalam penulisan karya ilmiah dianalisis dengan menggunakan Rumus yang dapat disajikan dalam bentuk persamaan berikut.

$$
P=\frac{\sum R}{\sum N} X 100 \%
$$

Keterangan :

$P \quad:$ persentase minat dan motivasi mahasiswa

$\Sigma R \quad$ : jumlah mahasiswa memilih jawaban Ya atau Tidak

$\Sigma N$ : jumlah mahaiswa yang mengisi angket

Persentase respon mahasiswa dikonversi dengan kriteria sebagai berikut:

Angka $0 \%-20 \%=$ Sangat lemah; Angka $21 \%-40 \%=$ Lemah; Angka $41 \%$ $60 \%=$ Cukup; Angka $61 \%-80 \%=$ Kuat; Angka $81 \%-100 \%=$ Sangat kuat (Riduwan, 2010)

\section{HASIL DAN PEMBAHASAN}

Penelitian ini dilakukan dalam dua tahap yaitu tahap pertama adalah tahap penyebaran angket tentang minat dan motivasi mahasiswa dan tahap kedua adalah analisis minat dan motivasi mahasiswa dalam penulisan karya ilmiah. Angket yang disebarkan adalah angket tertutup yang terdiri dari 20 pertanyaan dengan jumlah responden sebanyak 109 orang. Berikut akan diuraikan hasil penyebaran angket untuk memperoleh gambaran seberapa besar minat dan motivasi mahasiswa dalam penulisan karya ilmiah.

Tabel 1. Hasil Angket tentang Minat dan Motivasi Mahasiswa Pendidikan Matematika dalam Menulis Karya Ilmiah

\begin{tabular}{|c|c|c|c|c|c|}
\hline \multirow{2}{*}{$\begin{array}{l}\text { No } \\
\text { Item }\end{array}$} & \multirow{2}{*}{ Aspek } & \multicolumn{2}{|c|}{ Jumlah Responden } & \multicolumn{2}{|c|}{$\%$} \\
\hline & & Ya & Tidak & Ya & Tidak \\
\hline 1 & \multirow{3}{*}{$\begin{array}{l}\text { Penyelesaian masalah } \\
\text { mengunakan metode ilmiah }\end{array}$} & 92 & 17 & 84 & 16 \\
\hline 2 & & 82 & 27 & 75 & 25 \\
\hline 3 & & 39 & 71 & 36 & 64 \\
\hline 4 & \multirow{2}{*}{$\begin{array}{l}\text { Pengetahuan tentang karya } \\
\text { ilmiah }\end{array}$} & 86 & 23 & 79 & 21 \\
\hline 5 & & 81 & 28 & 74 & 26 \\
\hline
\end{tabular}




\begin{tabular}{|c|c|c|c|c|c|}
\hline \multirow{2}{*}{$\begin{array}{l}\text { No } \\
\text { Item }\end{array}$} & \multirow{4}{*}{ Aspek } & \multicolumn{2}{|c|}{ Jumlah Responden } & \multicolumn{2}{|r|}{$\%$} \\
\hline & & $\mathbf{Y a}$ & Tidak & $\mathbf{Y a}$ & Tidak \\
\hline 6 & & 84 & 24 & 77 & 23 \\
\hline 7 & & 96 & 13 & 88 & 12 \\
\hline 8 & \multirow{4}{*}{$\begin{array}{l}\text { Prosedur dan pengalaman } \\
\text { membuat karya ilmiah }\end{array}$} & 66 & 43 & 60 & 40 \\
\hline 9 & & 56 & 53 & 51 & 49 \\
\hline 11 & & 14 & 95 & 13 & 87 \\
\hline 12 & & 66 & 43 & 61 & 39 \\
\hline 13 & \multirow[t]{4}{*}{ Minat menulis karya ilmiah } & 95 & 14 & 87 & 13 \\
\hline 14 & & 101 & 8 & 93 & 7 \\
\hline 10 & & 92 & 18 & 84 & 16 \\
\hline 15 & & 93 & 16 & 85 & 15 \\
\hline 16 & \multirow[t]{5}{*}{ Motivasi menulis karya ilmiah } & 60 & 49 & 55 & 45 \\
\hline 17 & & 23 & 86 & 21 & 79 \\
\hline 18 & & 76 & 33 & 70 & 30 \\
\hline 19 & & 60 & 49 & 55 & 45 \\
\hline 20 & & 100 & 9 & 92 & 8 \\
\hline
\end{tabular}

Hasil sebaran angket yang terdapat pada tabel 1 di atas selanjutnya dikonversikan ke dalam beberapa kategori respon yang diadopsi dari Riduwan (2010). Data pada Tabel 1 menunjukkan bahwa sebesar $84 \%$ responden mampu mengidentifikasi masalah-masalah yang terjadi di sekitar mereka dan sebesar $75 \%$ dari reponden dapat memberikan solusi bagi masalah yang mereka temukan, akan tetapi solusi yang diberikan hanya sekedar pendapat semata tanpa dibuktikan melalui langkah-langkah metode ilmiah yang baik dan benar. Hal ini dapat dilihat dari besarnya persentasi responden yang berkisar 64\% responden tidak mengunakan langkah-langkah metode ilmiah untuk memecahkan masalah atau membuktikan kebenaran dari solusi yang mereka tawarkan. Padahal sebagian besar responden mempunyai wawasan yang baik tentang pengertian karya ilmiah, tujuan dan manfaat tentang penulisan karya ilmiah dengan persentasi di atas $74 \%$. Hal ini didukung oleh besarnya persentase responden yang menjawab bahwa pernah membaca karya ilmiah yaitu $88 \%$.

Data di atas menunjukkan bahwa pengetahuan responden tentang karya ilmiah cukup baik ditambah lagi sebagian besar mahasiswa pendidikan matematika dapat mengidentifikasi masalah-masalah di sekitar mereka dan dapat memberikan alternatif solusi untuk menjawab permasalahan yang mereka hadapi, akan tetapi pada umumnya mahasiswa pendidikan matematika belum menggunakan pengetahuan mereka untuk mengatasi permasalahan yang mereka hadapi menggunakan langkah-langkah dalam metode ilmiah. Gagasan, ide, pengalaman, teori atau penemuan yang diperoleh melalui membaca belum diaplikasikan 
secara nyata dalam kehidupan sehari-hari karena semuanya hanya sebatas memahami tanpa diaplikasikan dan ditulis dalam bentuk tulisan yang ilmiah.

Sebesar $60 \%$ responden menyatakan mengetahui prosedur penyusunan karya ilmiah akan tetapi hanya $51 \%$ yang menjawab pernah menyusun karya tulis ilmiah. Sebesar $13 \%$ responden menjawab pernah melakukan penelitian secara mandiri dan $61 \%$ menjawab pernah melakukan penelitian secara kelompok. Pada umumnya mahasiswa pendidikan matematika mengetahui prosedur dalam menyusun karya ilmiah tetapi kemampuan ini tidak diimbangi dengan minat mereka dalam membuat suatu karya ilmiah. Karya ilmiah yang dibuat pun lebih banyak secara kelompok daripada secara individu. Hal ini menunjukkan bahwa mahasiswa pendidikan matematika memiliki minat dan motivasi dalam penulisan karya ilmiah walaupun penelitian yang dilakukan oleh mahasiswa kebanyakan dilakukan secara berkelompok.

Sebanyak 93\% responden menjawab tertarik untuk menulis karya ilmiah dan $87 \%$ responden menyukai penelitian yang berkaitan langsung dengan masalah di masyarakat. Hal ini menunjukkan bahwa minat dan motivasi responden sangat kuat. $70 \%$ responden menjawab tetap termotivasi melakukan penelitian walaupun ada hambatan termasuk kategori respon kuat. $85 \%$ responden menjawab ketika menemukan masalah tidak berminat melakukan penelitian. Hal ini menunjukkan bahwa mahasiswa tertarik untuk menulis karya ilmiah tetapi rasa ingin tahu sangat rendah.

Selanjutnya sebanyak 55\% menjawab pernah diajak teman, dosen, lembaga universitas atau pemerintah untuk melakukan penelitian. Data ini menunjukkan bahwa dorongan dari luar untuk menumbuhkan minat dalam menulis pada mahasiswa cukup. Hal ini didukung juga oleh adanya dukungan dari program studi yang mewajibkan mahasiswa untuk menulis karya ilmiah pada mata kuliah tertentu dengan persentasi sebesar 55\% sedangkan $21 \%$ responden menjawab pernah mengajak teman, dosen, lembaga universitas atau pemerintah untuk melakukan penelitian bersama. 92\% responden menjawab termotivasi untuk melakukan penelitian ketika melihat orang lain melakukan penelitian tetapi motivasi intrinsik ini tidak ditindaklanjuti dengan penulisan karya ilmiah. Bagi mahasiswa yang pernah menulis karya ilmiah $70 \%$ responden menjawab melakukan penelitian walaupun ada hambatan yang menghalangi.

Berdasarkan data-data di atas, dapat diketahui bahwa mahasiswa Program Studi Pendidikan Matematika Universitas Flores memiliki minat dan motivasi untuk menulis karya ilmiah tetapi hanya sebagian kecil dari mereka yang menindaklanjuti dengan tindakan nyata yaitu menghasilkan suatu tulisan ilmiah. Minat dan motivasi mahasiswa dalam menulis 
karya ilmiah perlu ditingkatkan mengingat kemampuan dalam melaksanakan penelitian dan berpikir ilmiah untuk meningkatkan kinerja adalah salah satu kemampuan yang wajib dimiliki dalam kompetensi profesional guru. Mahasiswa pendidikan matematika adalah calon-calon guru yang disiapkan agar ketika lulus dapat menjadi guru yang profesional dalam bidang matematika dengan memiliki semua kemampuan di setiap kompetensi yang wajib dimiliki oleh seorang guru.

\section{KESIMPULAN DAN SARAN}

\section{Kesimpulan}

Berdasarkan hasil analisis, diskusi, dan pembahasan, maka dapat dibuat simpulan bahwa.

1. Minat mahasiswa pendidikan matematika dalam menulis karya ilmiah masuk kategori kuat karena berada pada kisaran diatas $70 \%$.

2. Motivasi intrinsik mahasiswa pendidikan matematika dalam menulis karya ilmiah lebih kuat daripada motivasi ekstrinsik. Hal ini ditunjukkan dengan data motivasi ekstrinsik mahasiswa sebesar 55\% sedangkan nilai motivasi instrinsik yang jauh lebih kuat yaitu sebesar $92 \%$.

\section{Saran}

Berdasarkan uraian pembahasan dan kesimpulan di atas, maka penulis menyarankan beberapa hal:

1. Minat dan motivasi mahasiswa dalam menulis karya ilmiah perlu ditingkatkan mengingat kemampuan dalam melaksanakan penelitian dan berpikir ilmiah dapat meningkatkan kinerja.

2. Perlu adanya pelatihan penulis karya ilmiah terhadap mahasiswa baru pada waktu kegiatan orentasi pengenalan kampus.

\section{Daftar Pustaka}

Kamus Besar Bahasa Indonesia (KBBI) Daring (Online) diakses di http://kbbi.kemdikbud.go.id pada tanggal 4 April 2015.

Kristiawan, M. 2015. Telaah Revolusi Mental dan Pendidikan Karakter Dalam Pembentukan Sumber Daya Manusia Indonesia Yang Pandai dan Berakhlak Mulia. Ta'dib, Volume 18, No.1: hal 13-25.

Lasa, Hs. 2009. Peran Perpustakaan dan Penulis dalam Peningkatan Minat Baca Masyarakat. UGM VISI PUSTAKA. Volume 11 No 2: hal 6-14. 
Makmun,A.S. 2012. Psikologi Kependidikan: Perangkat Sistem Pengajaran Modul. Bandung: PT. Remaja Rosdakarya.

Ormrod. 2008. Buku Psikologi Pendidikan: Membantu Siswa Tumbuh dan Berkembang Jilid 2. Jakarta: Penerbit Erlangga.

Riduwan. 2010. Skala pengukuran variabel-variabel penelitian. Bandung: Alfabeta.

Sanjaya, W. 2011. Kurikulum dan Pembelajaran. Jakarta: Kencana Prenada Media Group.

Sardiman, A.M. 2011. Interaksi dan Motivasi Belajar Mengajar. Jakarta: Rajawali Pers.

Slavin, R. 2011. Psikologi Pendidikan Edisi Kesembilan Jilid 2: Teori dan Praktik. Diterjemahkan oleh Samosir M, Jakarta: Pt Indeks Permata Puri Media.

Sudirman, S. 2012. Mengenal Karya Ilmiah. (Diakses di Sumber belajar/Belajar.kemdikbud.go.id diakses tanggal 6 juni 2015)

Sumiati dan Asra. 2007. Metode Pembelajaran. Bandung: Cv. Wacana Prima.

Widyahening, C.E. 2015. Penulisan Karya Tulis Ilmiah. Prosiding Seminar Nasional Pendidikan Universitas Sebelas Maret Surakarta, hal 20-27. Diterbitkan. 